\title{
Entangled Inequalities, State, and Social Policies in Contemporary Brazil
}

\section{Sérgio Costa}

\section{INTRODUCTION: ENTANGLED INEQUALITIES}

As a topic dating back to the very beginnings of sociology and economics, social inequalities have been subject to a wide array of definitions backed for different analytical and political purposes. In the past decades, neoclassical approaches rose to prominence both within the disciplinary field of economics and leading international organisations such as UN development agencies and the World Bank. This, in turn, resulted in a specific definition of inequalities that is dominant in international academia and politics alike: according to this interpretation, social inequalities refer to asymmetric individual chances to access socially valuable goods. Consequently, individual income differences within national borders as measured by the Gini index have become the central instrument to measure inequalities.

A first draft of this paper was delivered at the Workshop Rethinking Inequalities in Latin America, Bergen, and Norway, 5-6 March 2015, and at the University Aarhus, Denmark, on 7 October 2015. I thank the participants of these events as well as Luiz Carlos Bresser-Pereira and the editors of the present volume for valuable comments. I am alone responsible for eventually remaining imprecisions.

S. Costa $(\bowtie)$

Freie Universität Berlin, Berlin, Germany

(C) The Author(s) 2018

M. Ystanes, I.Å. Strønen (eds.), The Social Life of Economic

Inequalities in Contemporary Latin America, Approaches to Social

Inequality and Difference, DOI 10.1007/978-3-319-61536-3_3 
This narrow definition of inequalities presents practical advantages insofar as it offers a measurable basis for comparisons between individuals and national societies. However, it does not adequately take into account other crucial dimensions of inequalities as captured by more complex conceptualisations. Recent objections to this narrow definition can be classified into four groups related to the interest in researching inequalities: inequalities (1) of what, (2) between whom, (3) when, and (4) where. In the following, I will discuss these objections with regard to recent developments in Brazil. In particular, I will show how a more complex conceptualisation of inequality is necessary to adequately assess the gains in inequality reduction achieved during Brazil's engagement with the Pink Tide.

\section{Inequalities of What?}

A focus on inequalities of chances implicitly or explicitly rests on a liberal assumption according to which social positions in modern societies are solely or mainly determined by individual achievements. Therefore, if individuals have similar social opportunities, disparities in their life conditions allegedly reflect differences in terms of their individual effort. This supposition has been largely criticised by authors demonstrating that ascriptions concerning gender, race, ethnicity, and social prejudices remain relevant for individual opportunities of social mobility-also in contemporary societies (for an encompassing critique: Boatcă and Roth 2016). In Latin American societies, the role of ascriptions in shaping social inequalities is especially relevant due to the fact that being identified with categories coined to describe subordinated groups during the colonial period such as "black", "mestiza/mestizo", and "india/indio" still determines, to a large extent, the position occupied by individuals in current socio-economic hierarchies. In most cases, these colonial categories have been removed from the legal or policy framework, and, in cases where they do still appear, they are used not for discriminating against groups but rather for naming target groups of affirmative action policies in favour of blacks, women, indigenous peoples, and so on. However, as outlined in the introduction of this volume, these categories operate as ascriptive filters in everyday life, hindering the correspondent groups from accessing higher social positions, even in those cases for which formal equality of opportunities do exist. Because of this ascriptive bias, it seems analytically more accurate to shift the focus from inequality of opportunities in formal terms to inequality of results, understood as the 
final positions which individuals or groups of individuals achieve in the socio-economic structure.

Of course, socio-economic inequalities in terms of income and wealth are crucial for determining differences in concrete living conditions-after all, the wealthiest groups have better housing, better medical assistance, more and better leisure as well as longer life expectancies than groups which occupy a lower position in the social-economic structure. Nevertheless, two other dimensions of social inequalities, mostly faded out in conventional inequality research, are also decisive in determining distances between living conditions faced by different social groups: power asymmetries and socioecological inequalities. Power inequalities refers to both unequal capabilities to exert influence in decisions which affect one's personal trajectory and the asymmetric distribution of political and social rights and entitlements. Power asymmetries are obviously connected with socio-economic inequalities; however, they also encompass inequalities related to the level of enforcement of citizenship rights and welfare schemes. Accordingly, welfare states able to offer good public educational, health or transportation services enormously contribute to reducing the impact of (existing) socio-economic inequalities on (existing) living conditions (Kreckel 2004; Therborn 2013). In contrast, states which concentrate their social policies on cash transfers to the poor make only a small contribution to the reduction of disparities in living conditions (Lavinas 2013).

Socio-ecological inequalities, for their part, refers to both the unequal access to environmental goods such as fresh water, clean air, parks, and so on and the unevenly distributed capacity to obtain protection against ecological risks, including natural disasters and also manufactured jeopardies (pollution, irradiation, etc.). Provided that environmental goods are vastly commodified in contemporary societies and ecological risks can be outsourced and even exported, socio-ecological inequalities are not a lineal product of the "natural" geography of environmental goods and "bads". On the contrary, recent scholarship in this field defends the idea of a "constitutive interconnectedness" of nature and society inasmuch as:

Social relations of power and domination are constitutive for environmental problems; and vice versa that the way in which nature is appropriated, transformed and represented is constitutive for the (re-)production of social relations of power, domination and inequality. (Dietz 2014, 16) 
To sum up the arguments developed up to this point, researching inequalities from an encompassing perspective firstly requires a change of perspective, moving from inequalities of opportunities to inequalities of positions. Secondly, it implies a multidimensional concept of inequality able to consistently connect socio-economic, socio-ecological, and power inequalities.

\section{Inequalities Between Whom?}

Using concepts and references such as horizontal inequalities (in contrast to vertical inequalities; Stewart 2010), categorical inequalities (Tilly 1999), and intersectional inequalities (Anthias 2013, 2016), various authors stress the importance of researching inequalities not only between individuals but also between groups defined by social ascriptions. As summarised by Tilly,

[1]arge, significant inequalities in advantages among human beings correspond mainly to categorical differences such as black/white, male/female, citizen/foreigner, or Muslim/Jew rather than to individual differences in attributes, propensities, or performances. (Tilly 1999, 7)

Today, more than 15 years after the publication of Tilly's seminal book on durable inequalities, several studies in a variety of fields have demonstrated the importance of intermediate categories, between and within the seemingly binary constructions Tilly used, in determining social inequalities. For example, it has been shown that within the categorical pair citizen/ foreigner, one can identify key series of gradations such as the legal status of immigrants, their country of origin, and so on that determine their rights and possibilities, varying significantly among "foreigners" (see, e.g. Góngora-Mera et al. 2014). Similarly, as Lavra Pinto shows (this volume), there are significant inequalities within Rio de Janeiro's favelasnot just between favela residents and those of formal neighbourhoods. Moreover, the temporal aspect is often neglected: positions and labels adopted by individuals or groups may vary considerably over time, with groups who defined themselves as peasants later identifying themselves as indigenous or of African origin. That is to say that persistent inequality affecting similar demographic groups may be expressed by different categories (e.g. peasant, indigenous, indigenous women, etc.) in different historical circumstances (see Gonçalves and Costa 2016). Aside from that, definitions such as categorical inequalities or horizontal inequalities 
remain analytically useful because they reinforce the importance of social ascriptions in stabilising inequality patterns. In particular, intersectional approaches, for their part, have convincingly shown that positions in social structures always derive from complex interplays of categorisations of race, gender, class, and so on.

\section{Inequalities When?}

Economists usually study inequalities from a synchronic, contemporary perspective paying no attention to the fact that existing social structures reflect necessarily long-time historical processes (e.g. López-Calva and Lustig 2010).

Since the paradigmatic contribution of Tilly (1999), different studies have sought to enlarge their temporal perspective in order to unpack the historical formations of inequality structures. In the case of Latin America, several historiographic studies have reconstructed the nexus between contemporary inequalities and the history of this region shaped by colonialism, slavery, as well as by the reception of scientific racism after national independence (e.g. Stepan 1991; Andrews 2004). Conceptually, linking past and contemporary inequalities found in Latin America remains a challenge. This is because historically "persistent inequalities" have assumed new faces through history based on internal or external factors such as the enforcement of citizenship rights or the integration of local and global economies. Baquero (2015) draws on the geological metaphor "layered inequalities" to respond to this conceptual gap. According to this concept, inequalities which emerged in a certain historical epoch are superposed (but not substituted) by more recent structures of inequalities.

Other authors have also tried to solve this conceptual temporal problem by drawing on the idea of inequality regimes (Costa 2011; Góngora-Mera 2018). At the theoretical level, "inequality regimes" combines the idea of regime as a relational unity of analysis as found in concepts such as the human rights regime or the global climate regime with a more critical Foucauldian perspective, according to which a regime always implies power asymmetries and social control. A regime of inequality encompasses at least four dimensions: (i) logics of stratification/redistribution defined as static (caste societies), dynamic (class societies) or combined (class with racial/ ethnic/gender ascription); (ii) political, scientific, and popular discourses according to which individuals or groups interpret and construct their own positions and that of others in society; (iii) legal and institutional 
frameworks (e.g. apartheid law, multicultural or antidiscrimination laws, policies); and (iv) models of conviviality in everyday life (segregating or integrating convivial forms). Empirically, this approach has been applied to the study of inequalities which affect Afro-descendants in Latin America. In this case, we could identify four regimes of inequalities: slavery (until the nineteenth century), racist nationalism (from the end of the nineteenth century to the first decades of the twentieth century), Mestizo nationalism (from the 1930s to the 1980s), and the compensatory regime (from the 1980s). The transition to the next historical regime of inequality does not imply a complete disappearance of inequalities created in a previous regime. Consequently, racist discourses which had appeared during slavery, for instance, were later reinforced during the prevalence of racist nationalism. Packed in new imageries (emphasis rather on cultural than on the biological inferiority of blacks), these racist discourses subsisted Mestizo nationalism and are still present in the current regime of inequality characterised by compensatory policies in favour of black populations.

\section{Inequalities Where?}

While conventional scholarship researches inequalities on a local or national scale, new approaches seek for understanding inequalities with a widened angle in order to capture transnational and global entanglements that shape local and national social structures. There are two main approaches which have recently dealt with inequalities from an amplified perspective: while transnationalism (see, e.g. the contributions assembled in Weiß and Berger 2008) is interested in understanding how different national social structures interact, for instance, in the case of social positions of migrants, world systems approaches are rather concerned with macro-structural persistent inequalities (see, for instance, Korzeniewicz and Moran 2009).

In accordance with these new developments in the field of inequality research, the network desiguALdades.net-a research network on interdependent inequalities in Latin America-coined the concept of entangled inequalities ${ }^{1}$ understood as distances

[...] between positions of certain individuals or groups of individuals in a relationally (not spatially) determined context. This concerns economic positions (defined by income, access to resources and so on) as well as 
political and legal entitlements (rights, political power etc.). In order to understand the linkages from which unequal positions arise, it is necessary to have relational units of analysis that are dynamically defined in the process of inquiry itself. In a similar way, the interplay of social categorisations (gender, race, class, ethnicity etc.) cannot be articulated ex-ante in a formula. It can only be studied in the respective specific context. (Costa 2011, 21)

The approach "entangled inequalities" displays broad affinities with the interest of understanding inequalities in Latin America from an ethnographic perspective as outlined in the introduction of this book. Both the entangled inequalities and the ethnographic approach insist on the historical constitution and the intersectional character of social inequalities. Accordingly, both perspectives extend the scope of inequality research far beyond economic indicators in order to capture the impact of structural inequalities on lifeworlds. This does not imply a dichotomistic separation of social structures and everyday life, but just the opposite: by integrating the structural and life world dimensions of inequalities, these approaches shed light on the interconnections between these two dimensions to demonstrate that everyday interactions are both spaces of reproduction of social structures and also arenas in which social hierarchies are negotiated and transformed.

Recent changes promoted by Pink Tide governments in Latin America represent a privileged context to analyse the interplay between these two dimensions of inequalities. While cash transfer policies adopted by these governments have hugely reduced poverty, this kind of intervention has demonstrated a very limited power to transform "deep-seated aspects" of inequalities as described in the introduction of the present volume. Furthermore, if Pink Tide governments have tried to promote more emphatic shifts in existing social hierarchies, local elites have reacted by destabilising these governments. This happened in different terms but with a similar political plot in Argentina, Paraguay, and Brazil. The Brazilian case in particular is paradigmatic. Here, cash transfer policies have halved poverty rates in about 10 years. Real increases in the minimum wage and new economic opportunities created during the cycle of economic growth also started changing inequalities in everyday life, inasmuch as "newcomers" disputed spaces and goods of distinction reserved hitherto to the established middle classes. At this point oppositional forces became insurgent. Indeed, this dispute of previously reserved spaces and goods, in combination with the economic recession starting in 2015, led to the parliamentary coup d'état of 2016 (Costa 2018). 
However, exploring the impact on everyday life produced by the policies adopted during the Pink Tide cycle in Brazil would go beyond the scope of this chapter. Therefore, I limit myself to analysing the redistributive shortcomings of these policies, and, in doing so, applying the framework of entangled inequalities.

\section{Inequalities in Brazil: Recent Developments}

After the Workers' Party (PT) came to power in 2003, remarkable economic and social improvements have been reached in Brazil. Thus, in line with developments observed in several Latin American countries, inequalities in Brazil have declined in this period. During the two administrations of former President Lula da Silva (2003-2006 and 2007-2010) and the first administration of President Dilma Rousseff (2010-2014), economic growth, improvements in the labour market, progress in deprived regions, and pro-poor policies interacted positively as drivers of inequality reduction. Accordingly, between 2002 and 2013, GDP per capita has increased by 64 per cent, poverty rates among Brazilians-including extreme poverty-declined from 48.4 to 23.9 per cent of the Brazilian population, and social policy expenditures rose from 12.7 to 16.8 per cent of the Brazilian GDP (Bielschowsky 2014; CEPAL 2014). In the same period, the Brazilian labour market underwent an auspicious change as unemployment rates declined from 11.7 to 5.4 per cent among the economically active population while the formal employment rate has impressively increased from 49.7 per cent in 2003 to 71.4 per cent in 2012.

It was also between 2002 and 2013 that income inequality as measured by the Gini coefficient decreased from 0.59 to 0.53 . Yet despite this improvement, the Brazilian Gini coefficient for income is still above the Latin American average of 0.486 . With the richest quintile possessing 53.6 per cent of all income, Brazil also remains the most unequal Latin American country when it comes to income concentration by upper classes (as a comparison, this rate amounts to 36.4 per cent in Latin America's least unequal country, i.e. Uruguay; see CEPAL 2014).

Concerning inequalities related to racial and gender categorisations, they remain at a high level, but there has been also an important reduction of income asymmetries during the administrations led by the Workers' Party. In 2002, women's total average income represented only half of the male average income, while in 2012 this proportion rose to 58 per cent. A similar change can be observed for racial income asymmetries: 
In 2002 , the average income among blacks corresponded to 47 per cent of whites' average income. Yet in 2012, this proportion amounted to 55 per cent. A similar tendency can also be observed in the case of regional inequalities since the Northeast, Brazil's poorest region, has recently experienced more development than other regions. But regional inequalities still matter, especially if combined with gender and race-related asymmetries, as the figure below illustrates quite well (Fig. 3.1).

Among analysts of Brazilian social structure, there is a broad consensus that the reduction in inequalities between 2003 and 2015 is rather a consequence of economic processes (such as increasing prices for commodities in international markets and moves in domestic labour markets) than of social policies. Accordingly, social policies based on cash transfers have a crucial impact on poverty reduction, but they are seen to be less effective for promoting redistribution (Gaulard 2011; Lavinas 2013; Lustig et al. 2013).

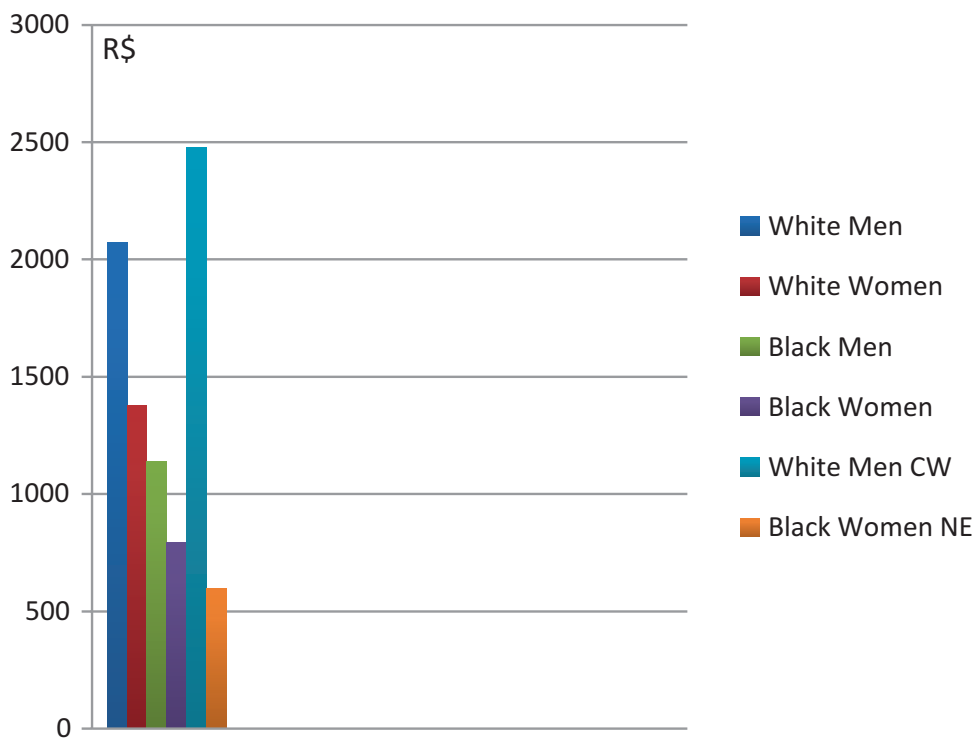

Fig. 3.1 Average monthly earnings in Brazil, 2012 (average earnings from the main occupation of the population over 16 years old) calculated for the intersection of inequality factors: sex, race, and region (figures in Brazilian Reais as of September 2012). NE Northeast, $C W$ Center West Source: Data from IBGE (2012) for selected groups 
Analysts also question the sustainability of the decrease in inequalities in Brazil given the current adverse confluence of modest (or even negative) economic growth, "premature" deindustrialisation, a "reprimarisation" of exports, and falling commodity prices. ${ }^{2}$

Inequality analysts are also concerned about recent political developments. Due to the economic stagnation and political instability, former President Dilma Rousseff, in her second administration started in 2015, faced serious difficulties in sustaining the social gains obtained during the previous administrations. At the end of 2015, the Brazilian congress started an impeachment process against President Rousseff, who has allegedly violated Brazilian budgetary laws. The president was first suspended in April of 2016 and finally removed from office in August 2016. Vicepresident Michel Temer assumed the government, promising to promote fiscal austerity and to cut social benefits introduced during the PT administrations. When he assumed the presidency, he first abolished the agency with ministerial status responsible for implementing policies meant to mitigate inequalities in terms of gender and race. In subsequent months, his administration has also adopted a series of unsocial and business-friendly measures, including but not limited to (i) a new programme of privatisation, ranging from oil exploration to public service, with the aim of boosting the economy; (ii) a constitutional amendment freezing social expenditures for 20 years which is expected to produce huge negative impacts for poor populations which are the most dependent on public services; and (iii) a plan to reform the pension system in a way which dramatically restricts benefits and increases contributions paid by employees (Fórum 21 et al. 2016).

\section{The (Re)Distributive Impact of State Intervention}

States remain key actors for promoting the mitigation of domestic inequalities created by economic interactions in capitalist societies - at least at the domestic level. Fiscal policies, including tax and social policies, and the offer of public and quasi-public goods represent classical instruments used by states to intervene in inequality structures. States can also intervene indirectly through measures - such as the introduction or increase of minimum wages - which lead to a redistribution in favour of low-paid workers.

Comparisons of the Gini coefficient before and after tax deductions and state transfers in different countries give a sense of how states use their redistributive power with very different intensities, as shown by data 
compiled by the World Bank (2014). Accordingly, the Gini coefficient before taxes and transfers in European OECD countries and in the Latin American countries is virtually identical. However, the final Gini coefficient, that is, after state's intervention through fiscal policy, is much higher in Latin American countries than in Europe. A comparison between two OECD countries, France and Mexico, makes this general tendency clear: the Gini coefficient in both countries before taxes and transfers is about 0.50. After fiscal policy, the French Gini coefficient decreases to 0.30 ; in Mexico it remains very high: 0.48.

Hence, Latin American states lack the power or the political will to strongly reduce market-produced income inequalities. In European countries, state interventions use to mitigate income inequalities by up to 50 per cent as, for instance, in the case of Slovenia and Norway (see World Bank 2014,27 ). Although distinctive patterns of state transfers (comprehending how much and for whom the state invests its resources) partly explain these contrasting results of state intervention between Europe and Latin America, the pivotal difference lies in the tax structures which are much more progressive in Europe than in Latin America. Pink Tide governments in Latin America have not changed this tendency since tax reforms recently implemented in the different countries aimed to increment tax revenues following established patterns. That is, tax systems continue to be based on a high taxation of salaries and consumption and low or even inexistent taxation of capital gains and profits (Jiménez and López Azcúnaga 2012).

In the case of Brazil, overall tax collection did in fact increase from 31.8 per cent of the GDP in 2003 to 35.9 per cent in 2012, exceeding thus the average number of OECD states which is 34.6 per cent (Castro 2014). However, the composition of tax revenues in Brazil differs substantially from that of those countries which are more effective in diminishing inequalities. While indirect taxes, which are regressive, ${ }^{3}$ represent 49.7 per cent of all collected taxes in Brazil, they held a much lower share of all collected taxes in European countries such as Germany (29.2 per cent) and Norway (27.3 per cent) (Castro 2014; data for 2012 from European Union 2014). In Brazil, the current composition of tax revenues has not varied substantively since the Workers' Party took office in 2003. This is also true for other regressive characteristics of the Brazilian tax system such as the lack of a tax on dividends (in Western European countries this taxation varies from 25 per cent in Belgium to 42 per cent in Denmark) and the low taxation of high incomes (in Brazil the highest income taxation is 27.5 per cent, whereas in Sweden, for instance, it amounts to 56.6 per cent). 
This tax collection structure is also unable to change the concentration of wealth encompassing properties and entitlements. Based on the analysis of more than 25 million tax declarations, Castro (2014) concludes that only 406,064 tax payers ( 0.2 per cent of the Brazilian population) possess about 47 per cent of Brazil's wealth. Also, he calculates the Gini coefficient for wealth which has remained practically stable since 2006, namely, around the extraordinarily high value 0.85 !

As far as income concentration is concerned, Castro simulates different changes in Brazilian taxation system and concludes that "merely" introducing a taxation of 15 per cent for capital and financial profits combined with tax rates of 35 and 40 per cent for high salaries could reduce the Gini coefficient by about 20 per cent. This would be more than what was achieved during the 12 years of PT administrations, the most successful period in terms of inequality reduction in Brazilian history. Before PT came to power, it was already aware of the impact of taxes on inequalities, as PT's electoral programme of 2002 unequivocally demonstrates:

The first reform to be faced by the new administration, during its very first year, will be a tax reform whose aim is improving economic efficiency and reducing social inequalities. (PT 2002, 14, translated from Portuguese by the author)

Dilma Rousseff also largely emphasised, during the impeachment hearings in the Brazilian Federal Senate in August of 2016, how the Brazilian tax system prevents wealth redistribution. Now, if PT and even the former Brazilian president acknowledged the impact of taxes on redistribution, why did Rousseff and her predecessor Lula not conduct a single attempt to change - at least minimally — the regressive Brazilian tax structure? Although social scientists have not yet offered a definitive answer to this question, it seems reasonable that the explanation should be sought in power relations: because of its conservative allies in the Brazilian congress and the support it received from different sectors which profit from a regressive tax structure, such as agribusiness, big concerns from the mining, beverage and construction sectors, and banks, PT's administrations did not feel strong enough to pass a tax reform contrary to the interests of the rich.

All in all, social policies recently implemented in Brazil have had a low impact on inequalities compared with the redistributive potential of the tax reforms outlined above. In order to assess the impacts of diverse strategies adopted by PT administrations, three policies will be discussed below: (1) the cash transfer programme Bolsa Família, (2) quotas at federal universities, and (3) a minimum wage. 


\section{Cash Transfer Programme: Bolsa Familia}

As soon as the PT came into power, this programme of direct cash transfers to poor families with schoolchildren became the most outstanding feature of PT administrations. While a previous programme created during the former administration of Fernando Henrique Cardoso provided benefits for 3.6 million families in 2002, the Bolsa Família benefited 14.1 million families with about R\$ 142 in 2013 (see Bielschowsky 2014). Bolsa Família's main recipients are women (93 per cent) and blacks (73 per cent).

Bolsa Família has played a pivotal role in reducing poverty in Brazil, although its costs are modest: Financed by public funding representing only 0.5 per cent of the Brazilian GDP, the programme reaches 25 per cent of the Brazilian population (see Pinto's Chap. 6 in this book). Nevertheless, Bolsa Família has a negligible relevance for mitigating income inequality: Bolsa Família and other cash transfer measures merely respond to 1 per cent of the Gini coefficient composition (according to Medeiros and de Souza 2013; see also Lavinas 2007, 2013).

The new administration led by Michel Temer first kept the programme. However, it has adopted several administrative measures to reduce the number of programme beneficiaries (Carta Capital 2016).

\section{Quotas at Federal Universities}

Although some policies had been already introduced by previous governments, the Workers' Party implemented a broad set of new policies to mitigate inequalities associated with gender and racial ascriptions. To accomplish this, two extraordinary agencies with ministerial status were also created in 2003: one for policies targeting women (SEPM) and another for policies promoting racial equality (SEPPIR). As shown elsewhere (Costa 2015), most of the measures implemented concentrate on combating discrimination which is only one among several mechanisms at work in the reproduction of racial and gender asymmetries. Additionally, the measures adopted reach only a small fragment of black or female Brazilians. The quota programme introduced in Brazilian federal universities in 2012 is one such case.

According to the programme, 50 per cent of all study placements at federal higher education institutions are to be reserved for students graduating from public schools and allocated according to the proportion of the black and indigenous populations living in the respective region. Yet, when taking into account that in 2013 only about 1.1 million of all 
7.3 million undergraduate students in Brazil were enrolled at federal institutions (INEP 2014), and when also considering that blacks and indigenous represent about $5 \mathrm{l}$ and 0.5 per cent respectively of the whole Brazilian population, then it is clear that the federal quotas programme, if fully implemented, will only distribute approximately 283,000 university places according to racial/ethnic criteria. Therefore, the programme, because of its design, benefits a small group among the more than 100 million blacks und 800,000 indigenous living in Brazil, producing only minimal socio-economic aggregate effects. According to its opponents, the programme also contributes to racialising everyday relations since beneficiaries are forced to recognise themselves according to ethnoracial categories, this despite the fact that Brazilian society is characterised by the existence of a porous system of colour classification rather than a dichotomistic opposition between blacks and whites. Defenders of quota policies argue that, far beyond the still dominant self-representation of the Brazilian nation of a Mestizo country without sharp divisions between blacks and whites, lifeworlds of blacks and whites are to a large extent separated since they go to different schools, use different means of transport, and live in distinct residential areas. In this context, policies such as quotas rather promote interracial coexistence in a racially segregated society (for an overview of these arguments see Costa 2017).

That being said, critics do not delegitimise the programme because it has an obvious relevance for setting the imperative of overcoming racism in the core of Brazil's political agenda, even if its impact on promoting socio-economic redistribution in favour of the black or indigenous population as a whole is marginal.

Until February of 2017, when the present article was concluded, Temer's administration has not abolished the system of quotas at federal universities. However, federal universities suffered a cut of about 45 per cent in their budget with serious consequences for their quality and for their capacity to provide an adequate academic environment for students admitted through the quotas (Vieira 2016).

\section{Minimum Wage}

In response to consistent political pressure articulated by national associations of trade unions, the Brazilian government has readjusted the minimum wage in real terms consecutively since 2003. Since 2008, the adjustments have been coupled by law to inflation and the economic 
growth rate of 2 years prior to the increase. This policy has led to a real increase in the minimum wage by 75 per cent between 2002 and 2013 and is seen as the most important driver of the recent decline of inequalities in Brazil (Sabóia and Hallek Neto 2016; UNDP 2014). There are multiple factors explaining the redistributive effects of the minimum wage:

(1) Since about 70 per cent of Brazilian workers have an income of less than double the minimum wage per month, a real increment of minimum wage automatically leads to an improvement of wellbeing for a significant part of the population (DIEESE 2014).

(2) The rise in minimum wage reinforces the bargaining power of workers whose salaries are not coupled with the minimum wage and even for informal workers the minimum wage serves "as a benchmark for individual wage negotiations" (Berg 2012, 8).

(3) The automatic readjustment of lower pension values to the minimum wage results in real income improvements for the elderly and their families in the lower classes.

(4) Since women and blacks are overrepresented in low-wage labour sectors such as domestic work, which are directly governed by the minimum wage law, real increases of the minimum wage contribute to reduce inequalities in terms of gender and race (IPEA 2013).

This methodology for adjusting minimum wage had positive impacts for mitigating inequalities as long as the Brazilian economy presented high growth rates. However, since 2014, Brazilian GDP has dramatically contracted which will lead to a reduction of minimum wage in real terms with adverse consequences for redistribution in both terms: class, as well as gender, and race.

\section{Conclusion: Entangled Inequalities and Recent DEVELOPMENTS IN BRAZIL}

If the general framework of entangled inequalities is applied to assess the recent decline of inequality in Brazil, certain ambivalences in this process stand out. At the level of income differences, social distances were-at least until 2015-slightly reduced. However, this does not necessarily lead to a less unequal access to "socially-relevant goods" since wealth concentration remains virtually unaffected, and access to public and common goods such as a healthy environment and a well-functioning public transport system 
may have become even more unequal. ${ }^{4}$ The missing sustainability of inequality reduction should be emphasised, too. As soon as the Brazilian economy started stagnating, less skilled workers were the first to lose their jobs, and with them, the better social position they had achieved during the Pink Tide cycle (Costa 2018).

The assessment of power asymmetries as a key aspect of the entangled inequalities approach is a complex endeavour since transparent indicators for measuring power asymmetries are not available. In general terms, it can be stated that the PT administrations have not represented a radical power shift in favour of the working and lower classes. Otherwise, these administrations would have reformed the regressive tax system targeting capital and financial profits. Notwithstanding, some particular groupsespecially women and Afro-descendants-have been empowered insofar as their claims have been inserted on a large scale into the political agenda, being addressed by compensatory policies. However, these political gains are tenuous, since they were institutionalised not as rights granted by solid welfare institutions but as benefits within transitory social programmes (Lavinas 2013). Drawing on the vocabulary Chatterjee (2004) applies to analyse Indian politics, we can state that in the framework of the social programmes introduced by PT administrations, beneficiaries represent target populations, which have entitlements, but not full citizens with unnegotiable rights. With this distinction, I am not negating the huge relevance of these programmes for reducing poverty and temporarily empower minorities. My intention is to emphasise some insufficiencies of these policies to produce a power shift in favour of the poor and minorities in Brazil both in everyday life and at the level of political institutions. These policies, by establishing conditions of access (such as regular submission to certain medical exams, regular attendance of schools, etc.) and sanctions in the case that this conditionality is not observed represent rather a "dispositive to control the population" than an instrument to empower citizens (Bueno 2009, 44). Institutionally, most social policies adopted by PT administrations assumed the framework of social programmes and thus were not integrated into the Brazilian constitution as citizenship rights. As a consequence, there is only a very low institutional and political hurdle to abolish and remove them as witnessed in contemporary Brazilian politics. Indeed the fragility of gains for the poor and for less empowered groups such as the Afro-descendant population and women, obtained during the PT administrations, became evident when the former Vice President Temer assumed the government after Rousseff's 
impeachment. Using simple administrative measures, Temer's government could cut important social and political benefits these groups had obtained in recent years.

The dynamic of inequality reduction in Brazil speaks in favour of an intersectional approach able to integrate the complex entanglements between the varieties of inequalities concerning class, racial, gender, and regional ascriptions. It has been shown above that since class, gender, and racial disadvantages interact, policies aimed to reduce class inequalities such as Bolsa Família or a minimum wage bring more improvements for much more blacks and women at the level of income than policies exclusively designed to reduce gender and racial asymmetries accumulated throughout history. Nevertheless, affirmative action policies in favour of blacks, indigenous, or women remain crucial for reducing both power asymmetries as well as racism and sexism in everyday relations. Inasmuch as more blacks, women, and indigenous obtain an academic degree and occupy leading positions in hierarchically structured organisations and social spaces, they contribute to removing prejudices constructed over centuries of white and male supremacy and to transforming equality assured at the formal level into lived experience.

\section{Notes}

1. The use of the expression "entangled inequalities" is inspired by discussions on entangled modernity as developed by Conrad and Randeria (2002). A more detailed discussion on the concept entangled inequalities is developed in Costa (2011), Lillemets (2013), Braig et al. (2015) and Jelin et al. (2018).

2. Economists use the expression premature deindustrialisation (desindustrialização precoce) to refer to the current process of abrupt declining participation of industrial production in Brazilian GDP, a phenomenon that appears before the industrial sector is fully consolidated. Accordingly, deindustrialisation is motivated by a combination of a persistent overvalued currency (this situation has only changed within the economic and political crisis of 2015 ) leading to a stimulation of import of industrial products, high rates of interest which discourages industrial investments, and low level of foreign investment. "Reprimarisation" refers to an increasing participation of agrarian and mining products in exports (Cano 2012; Costa et al. 2015).

3 . The regressive character of taxes associated with consumption derives from the fact that underprivileged classes spend a much greater proportion of their income on consumption than rich families do. Using data from 2008, IPEA (2009) calculated that while families with an income of up to twice 
the minimum wage spent 53.9 per cent of their income paying taxes, those receiving more than thirty times the minimum wage spent 29 per cent on their taxes. The minimum wage corresponds to about US\$297 per month (according to the exchange rate of 31 January 2017).

4. Although this paper does not address access to public and common goods, the topic is mentioned here in order to illustrate some implications of using the entangled inequalities approach. Moreover, several studies indicate that access to public and common goods has become increasingly unequal in contemporary Brazil. The case of access to transportation and a wellfunctioning traffic system is a striking example: Between 2003 and 2013, the number of registered vehicles in Brazil jumped from about 37 million to about 82 million (DENATRAN 2015). This has triggered a rise in traffic accidents with fatal victims especially among pedestrians and motorcyclists, those road users with lower incomes (Bacchieri and Barros 2011).

\section{BIBLIOGRAPHY}

Andrews, George R. 2004. Afro-Latin America, 1800-2000. Oxford: Oxford University Press.

Anthias, Floya. 2013. Social Categories, Embodied Practices, Intersectionality: Towards a Translocational Approach. In Interdependencies of Social Categorisations, ed. Daniela Célleri, Tobias Schwarz, and Bea Wittger, 7-26. Madrid/Frankfurt: Iberoamericana/Vervuert.

- 2016. Interconnecting Boundaries of Identity and Belonging and Hierarchy-Making Within Transnational Mobility Studies: Framing Inequalities. Current Sociology 64 (2): 172-190.

Bacchieri, Giancarlo, and Aluísio J.D. Barros. 2011. Traffic Accidents in Brazil from 1998 to 2010: Many Changes and Few Effects. Revista Saúde Pública 45 (5): 949-963.

Baquero, J. 2015. Layered Inequalities. Land Grabbing, Collective Land Rights, and Afro-descendant Resistance in Colombia. Berlin et al.: LIT Verlag.

Berg, Janine. 2012. Labour Market Institutions for Just Societies. Geneva: International Labour Office.

Bielschowsky, Ricardo. 2014. O modelo de desenvolvimento proposto por Lula e Dilma. In Brasil em Debate. http://brasildebate.com.br/o-modelo-de-dedesenvolvimento-proposto-por-lula-e-dilma/\#sthash.WtLZN74s.dpuf. Accessed 2 Feb 2017.

Boatcă, Manuela, and Julia Roth. 2016. Unequal and Gendered: Notes on the Coloniality of Citizenship. Current Sociology 64 (2): 191-212.

Braig, Marianne, Sérgio Costa, and Barbara Göbel. 2015. Desigualdades sociales e interdependencias globales en América Latina. Una valoración provisional. Revista Mexicana de Ciencias Politicas y Sociales 40 (233): 209-236. 
Bueno, Marina. 2009. As Condicionalidades do Programa Bolsa Família: O Avesso da Cidadania. Lugar Comun 29: 33-46.

Cano, Wilson. 2012. A desindustrialização no Brasil. Economia \& Sociedade 21 (Special Issue): 831-851.

Carta Capital. 2016. Governo Temer suspende 1,1 milhão de benefícios do Bolsa Família. Carta Capital, November 07. http://www.cartacapital.com.br/politica/governo-temer-suspende-1-1-milhao-de-beneficios-do-bolsa-familia. Accessed 2 Feb 2017.

Castro, Fábio A. de. 2014. Imposto de renda da pessoa física: comparações internacionais, medidas de progressividade e redistribuição. Unpublished Master Thesis, Brasília, UnB.

Chatterjee, Partha. 2004. The Politics of the Governed. New York: Columbia University Press.

Comisión Económica para América Latina y el Caribe. CEPAL. 2014. Panorama Social de América Latina 2014. Santiago de Chile: CEPAL.

Conrad, Sebastian, and Shalini Randeria. 2002. Einleitung. Geteilte Geschichten Europa in einer postkolonialen Welt. In Jenseits des Eurozentrismus. Postkoloniale Perspektiven in den Geschichts- und Kulturwissenschaften, ed. Sebastian Conrad and Shalini Randeria, 9-49. Frankfurt a.M.: Campus.

Costa, Sérgio. 2011. Researching Entangled Inequalities in Latin America: The Role of Historical, Social, and Transregional Interdependencies. desiguALdades. net Working Paper Series 9. Berlin: desiguALdades.net Research Network on Interdependent Inequalities in Latin America, 2015. http://www.desigualdades.net/Working_Papers/index.html

- 2015. Protection Without Redistribution? Conceptual Limitations of Policies Meant to Reduce Inequalities Concerning Race and Gender in Brazil. In A Moment of Equality for Latin America? Challenges for Redistribution, ed. Barbara Fritz and Lena Lavinas, 235-252. Farnham: Ashgate.

- 2017. Dilemmas of Inter-American Anti-Racism. Re-visiting 'On the Cunning of Imperialist Reason'. In The Routledge Companion to InterAmerican Studies, ed. Willfried Raussert, 338-349. London: Routledge.

- 2018. Millionaires, the Established, the Outsiders, and the Poor. Social Structure and Political Crisis in Brazil. In Global Entangled Inequalities: Conceptual Debates and Evidence from Latin America, ed. Elizabeth Jelin, Renata C. Motta, and Sérgio Costa, 178-195. London: Routledge.

Costa, Sérgio, Barbara Fritz, and Martina Sproll. 2015. Dilma 2: From Economic Growth with Distribution to Stagnation and Increasing Inequalities? Latin American Studies Association Forum XLVI (2): 21-24. https://lasa.international.pitt.edu/forum/past-issues/vol46-issue3.asp

Departamento Intersindical de Estatística e Estudos Socioeconômicos. DIEESE. 2014. A política de valorização do Salário Mínimo: persistir para melhorar. Nota Técnica No. 136. 
Departamento Nacional de Trânsito. DENATRAN. 2015. Frota de veículos. http://www.denatran.gov.br/index.php/estatistica/237-frota-veiculos. Accessed 2 Feb 2017.

Dietz, Kristina. 2014. Researching Inequalities from a Socio-ecological Perspective, desiguALdades Working Paper Series 71. Berlin: desiguALdades.net Research Network on Interdependent Inequalities in Latin America. http://www. desigualdades.net/Resources/Working_Paper/74-WP-Dietz-Online.pdf

European Union. 2014. Taxation Trends in the European Union: Data for the EU Member States, Iceland and Norway. Luxembourg: Publications Office of the European Union.

Fórum, 21; Fundação Friedrich Ebert Stiftung (FES); GT de Macro da Sociedade Brasileira de Economia Política (SEP); and Plataforma Política Social. 2016. Austeridade e Retrocesso. São Paulo: Fórum 21, FES, SEP and Plataforma Política Social. http://brasildebate.com.br/wp-content/uploads/Austeridadee-Retrocesso.pdf

Gaulard, Mylène. 2011. Balance sobre la cuestión de las desigualdades en Brasil. Revista Problemas del Desarrollo 166 (42): 111-134.

Gonçalves, Guilherme L., and Sérgio Costa. 2016. The Global Constitutionalization of Human Rights: Overcoming Contemporary Injustices or Juridifying Old Asymmetries? Current Sociology 64 (2): 311-331.

Góngora-Mera, Manuel. 2018. Transregional Articulations of Law and Race in Latin America: A Legal Genealogy of Inequality. In Global Entangled Inequalities: Conceptual Debates and Evidence from Latin America, ed. Elizabeth Jelin, Renata C. Motta, and Sérgio Costa, 43-58. London: Routledge.

Góngora-Mera, Manuel, Gioconda Herrera, and Conrad Müller. 2014. The Frontiers of Universal Citizenship Transnational Social Spaces and the Legal Status of Migrants in Ecuador, desiguALdades Working Paper Series 71. Berlin: desiguALdades.net Research Network on Interdependent Inequalities in Latin America. http://www.desigualdades.net/Working_Papers/index.html

Instituto Brasileiro de Geografia e Estatística. IBGE. 2012. Pesquisa Nacional por Amostra de Domicilios. Brasília: IBGE. http://www.ibge.gov.br/home/estatistica/populacao/trabalhoerendimento/pnad2012/default_sintese.shtm. Accessed 2 Feb 2017.

Instituto de Estudos e Pesquisas Educacionais Anísio Teixeira. INEP. 2014. Censo da Educação Superior 2013. Brasília: INEP.

Instituto de Pesquisa Econômica Aplicada. IPEA. 2009. Receita pública: quem paga e como se gasta no Brasil. Brasília: IPEA.

- 2013. Retrato das Desigualdades de Gênero e Raça. 4th ed. Brasília: IPEA. Jelin, Elizabeth, Renata C. Motta, and Sérgio Costa. 2018. Global Entangled Inequalities: Conceptual Debates and Evidence from Latin America. London: Routledge. 
Jiménez, Juan P., and Isabel López Azcúnaga. 2012. ¿Disminución de la desigualdad en América Latina? El rol de la politica fiscal, desiguALdades.net Working Paper Series 33. Berlin: desiguALdades.net Research Network on Interdependent Inequalities in Latin America. http://www.desigualdades.net/Working_Papers/ index.html

Korzeniewicz, Roberto P., and Timothy P. Moran. 2009. Unveiling Inequality: A World-Historical Perspective. New York: The Russell Sage Foundation.

Kreckel, Reinhard. 2004. Politische Soziologie der sozialen Ungleichheit. Frankfurt: Campus.

Lavinas, Lena. 2007. Gasto social no Brasil: programas de transferência de renda versus investimento social. Ciência \& Saúde coletiva 12 (6): 1463-1476.

- 2013. 21st Century Welfare. New Left Review 84 (6): 5-40.

Lillemets, Krista. 2013. Global Social Inequalities: Review Essay, desiguALdades. net Working Paper Series 45. Berlin: desiguALdades.net Research Network on Interdependent Inequalities in Latin America. http://www.desigualdades.net/ Working_Papers/index.html

López-Calva, Luis F., and Nora Lustig Lustig, eds. 2010. Declining Inequality in Latin America: A Decade of Progress? Baltimore: UNDP, Brookings Institution Press.

Lustig, Nora, Carola Pessino, and John Scott. 2013. The Impact of Taxes and Social Spending on Inequality and Poverty in Argentina, Bolivia, Brazil, Mexico, Peru and Uruguay: An Overview. CEQ Working Paper No. 13.

Medeiros, Marcelo, and Pedro H.G.F. de Souza. 2013. Estado e desigualdade de renda no Brasil: fluxos de rendimentos e estratificação social. Revista Brasileira de Ciências Sociais 28 (83): 141-150.

PT - Partido dos Trabalhadores. 2002. Programa de Governo 2002. São Paulo: Fundação Perseu Abramo.

Sabóia, João, and João Hallak Neto. 2016. Minimum Wage and Income Distribution in Brazil from the 2000s, Nopoors Working Paper 44. http:// www.nopoor.eu/publication/minimum-wage-and-income-distribution-brazil2000s. Accessed 2 Feb 2017.

Stepan, Nancy L. 1991. The hour of eugenics. In Race, Gender, and Nation in Latin America. Ithaca/London: Cornell University Press.

Stewart, Frances. 2010. Por qué persisten las desigualdades de grupo? Las trampas de la desigualdad horizontal. In Teoría económica y desigualdad social. Exclusión, desigualdad y democracia. Homenaje a Adolfo Figueroa, ed. Félix Jiménez, 269-298. Lima: Fondo Editorial de la PUC-Perú.

Therborn, Göran. 2013. The Killing Field of Inequality. Cambridge: Polity Press.

Tilly, Charles. 1999. Durable Inequality. Berkeley/Los Angeles/London: University of California Press.

United Nations Development Programme. UNDP. 2014. Humanity Divided: Confronting Inequality in Developing Countries. New York: UNDP. 
Vieira, Victor. 2016. Universidades federais devem ter corte de até $45 \%$ nos investimentos. O Estado de S. Paulo, 11 August.

Weiß, Anja, and Peter A. Berger. 2008. Transnationalisierung sozialer Ungleichheit. Wiesbaden: VS.

World Bank. 2014. Social Gains in the Balance: A Fiscal Police Challenge for Latin America and the Caribbean. Washington, DC: World Bank.

Open Access This chapter is licensed under the terms of the Creative Commons Attribution 4.0 International License (http://creativecommons.org/licenses/ by $/ 4.0 /$ ), which permits use, sharing, adaptation, distribution and reproduction in any medium or format, as long as you give appropriate credit to the original author(s) and the source, provide a link to the Creative Commons license and indicate if changes were made.

The images or other third party material in this chapter are included in the chapter's Creative Commons license, unless indicated otherwise in a credit line to the material. If material is not included in the chapter's Creative Commons license and your intended use is not permitted by statutory regulation or exceeds the permitted use, you will need to obtain permission directly from the copyright holder.

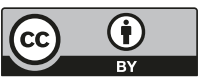

